\title{
THE FEDERAL SENTENCING GUIDELINES AND CONFRONTATION RIGHTS
}

\author{
DAVID A. HOFFMAN $\dagger$
}

INTRODUCTION

Drug Enforcement Agency (DEA) agents arrested and convicted John Doe for selling five marijuana cigarettes to Mary Smith. The prosecutors promised John that if he pleaded guilty, they would recommend no jail time. John entered a guilty plea, but at sentencing, DEA agents introduced testimony from an undisclosed informant who stated that over a four-year period, the informant had bought a total of one kilogram of marijuana from John in fifty different transactions. The informant also stated that the drug sales had taken place on the same street corner, at the same time of day, and with the same intricacies of exchange as John's sale to Mary.

John admitted selling the drugs to Mary, but protested strenuously that he was not responsible for the other sales. John was telling the truth: The informant invented the information so that he would receive future leniency from the agents. However, neither the agents nor the judge discovered that the informant had fabricated the story.

The DEA agents maintained that the informant had always been reliable in the past. John, however, never learned the identity of the informant; nor was he ever given the opportunity to confront the informant's testimony. The sentencing judge determined, from the agents' comments, that there were enough "particularized guarantees of trustworthiness"1 to allow the one kilogram of marijuana to be considered under the U.S. Sentencing Guidelines' definition of "same course of conduct." When the

$\dagger$ With thanks and gratitude to Professor Sara Sun Beale for her inspiration and encouragement. Also special thanks to Professors Robert Simon and Rick Werner for their advice and guidance.

1. Ohio v. Roberts, 448 U.S. 56, 66 (1980).

2. UNITED STATES SENTENCING COMMISSION, Guidelines MANUAL $\S 1 B 1.3$ (Nov. 1991) [hereinafter GUIDELINES MANUAL]. 
judge added the one kilogram to the five marijuana cigarettes ( 2.5 grams), ${ }^{3}$ the total was 1.0025 kilograms.

The judge sentenced John for a level 10 offense. Absent the informant's testimony the judge would have sentenced John for a level 6 offense. ${ }^{4}$ Under a level 6 offense, John might not have had to serve any time in prison, assuming he had no criminal history. Under the level 10 offense, however, John would have to serve a minimum of six months in jail, with a possible sentence of twelve months. ${ }^{6}$ John would have to serve this jail time despite his deal with the prosecutors. If John's right to confront his accusers had extended to sentencing, he might have been able to show that the informant's testimony was false. John's situation, although hypothetical, demonstrates the real possibility for injustice under the Federal Sentencing Guidelines.

The Sentencing Reform Act of $1984^{7}$ created the United States Sentencing Commission (the Commission). ${ }^{8}$ Congress gave the Commission the task of promulgating binding federal sentencing guidelines (the Guidelines). ${ }^{9}$ The Guidelines took effect in 1987 and courts have imposed them for offenses committed after November $1,1987 .{ }^{10}$ Many courts, though, have expressed concern that defendants are not adequately protected under the new system. ${ }^{11}$ In particular, some courts have held that confrontation rights should extend to sentencing. ${ }^{12}$

Confrontation rights find their source in the Due Process Clause of the Fourteenth Amendment ${ }^{13}$ and the Confrontation

3. Id. $\S 2 \mathrm{D} 1.1$. Each marijuana cigarette is converted to .5 gram, or .0005 kilogram.

4. See id. The Sentencing Guidelines prescribe higher sentences for higher levels.

5. See id. § 5A (sentencing table).

6. See id.

7. Pub. L. No. $98-473$, ch. 2,98 Stat. 1987 (1984) (codified principally at 18 U.S.C. $\S \S 3551-3673$ and 28 U.S.C. $\S \S 991-998$ (1988)).

8. 28 U.S.C. $\S 991$ (a) (1988).

9. Id. § 994(a).

10. Sentencing Reform Act of $1984, \S 235(\mathrm{a})(1), 98$ Stat. at 2031 , as amended by Pub. L. No. 99-217, §§ 2, 4, 99 Stat. 1728 (1985); Pub. L. No. 99-646, § 35, 100 Stat. 3599 (1986); Pub. L. No. 100-182, \& 2, 101 Stat. 1266 (1987); see generally William W. Wilkins, Jr. \& John R. Steer, Relevant Conduct: The Cornerstone of the Federal Sentencing Guidelines, 41 S.C. L. REV. 495, 496 (1990).

11. See, e.g., United States v. Kikumura, 918 F.2d 1084, 1100 (3d Cir. 1990) (Circuit Judge Edward Becker criticizing the lack of procedural protection for some defendants).

12. See, e.g., United States v. Fortier, 911 F.2d 100 (8th Cir. 1990), overnuled by United States v. Wise, 976 F.2d 1502 (8th Cir. 1992).

13. The Fourteenth Amendment provides, in part, "[N]or shall any State deprive any 
Clause of the Sixth Amendment. ${ }^{14}$ The Supreme Court early on applied to the states procedural safeguards that were "implicit in the concept of ordered liberty",is courts therefore addressed confrontation issues under the Due Process Clause of the Fourteenth Amendment. More recent cases have focused on the attributes of the actual criminal justice system involved..$^{16}$ In 1965 , the Supreme Court held that the Confrontation Clause applied to the states through the Fourteenth Amendment. ${ }^{17}$ From that point on, courts addressed confrontation rights either under the Due Process Clause of the Fourteenth Amendment or the Confrontation Clause of the Sixth Amendment. Since the Bill of Rights was extended to the states, both the Due Process Clause and the Confrontation Clause have been addressed by the courts. The two protections are often grouped together as "confrontation rights" or simply "confrontation."

This Note advocates that confrontation rights should apply to sentencing under the Guidelines. Without confrontation rights at sentencing, defendants are not adequately protected. Defendants did not need these protections under the old sentencing system because the sentencing judge exercised a large degree of discretion. ${ }^{18}$ Under the Guidelines, however, sentences are imposed mandatorily; some courts therefore have held that under the Guidelines confrontation rights should be extended to sentencing. ${ }^{19}$

person of life, liberty, or property, without due process of law . . ."

U.S. CONST. amend. XIV, § 1.

14. The Sixth Amendment provides:

In all criminal prosecutions, the accused shall enjoy the right to a speedy and public trial, by an impartial jury of the State and district wherein the crime shall have been committed, which district shall have been previously ascertained by law, and to be informed of the nature and cause of the accusation; to be confronted with the witnesses against him; to have compulsory process for obtaining witnesses in his favor, and to have the Assistance of Counsel for his defence.

U.S. CONST. amend. VI (emphasis added).

15. Palko v. Connecticut, 302 U.S. 319 (1937).

16. See, e.g., Duncan v. Louisiana, 391 U.S. 145 (1968).

17. Pointer v. Texas, 380 U.S. 400 (1965).

18. Williams v. New York, 337 U.S. 241, 248 (1965).

19. See, e.g., United States v. Silverman, 1991 WL 179608 (6th Cir. Sept. 17, 1991), vacated, 976 F.2d 1502 (6th Cir. 1992) (en banc); United States v. Fortier, 911 F.2d 100 (8th Cir. 1990), overruled by United States v. Wise, 976 F.2d 393 (8th Cir. 1992). Although these cases were reversed, the initial arguments for cxtending confrontation rights remain compelling. 
Part I of this Note describes the differences between sentencing before the enactment of the Guidelines and sentencing under the Guidelines regime. Under the earlier, indeterminate system, judges maintained a wide degree of latitude in sentencing. Now the Guidelines restrict judges' discretion by mandating sentencing ranges. Part II outlines the caselaw applying confrontation rights to sentencing. Cases under the indeterminate system rejected extending confrontation rights, but recent cases under the Guidelines have advocated extending them. Part III analyzes the arguments for and against applying confrontation rights to sentencing. Finally, Part IV concludes that both the Due Process Clause of the Fourteenth Amendment and the Confrontation Clause of the Sixth Amendment mandate confrontation rights at sentencing under the Guidelines.

\section{A TALE of Two SySTEMS}

This Part traces the development of sentencing from the former indeterminate system to the current guidelines system. Section A describes the old system, which, based on the theory that prisoners could be rehabilitated, gave sentencing judges a large amount of discretion to determine which prisoners required more rehabilitation than others. Section $B$ explains the process by which sentencing has changed; Congress started the process by defining the goals for a new Guidelines system, then established a Sentencing Commission to implement these goals. Section $\mathrm{C}$ outlines how the Guidelines function, and shows how the different requirements of the Guidelines work to define each prisoner's sentence.

\section{A. Indeterminate Sentencing}

Prior to the enactment of the Guidelines, the federal government had for over a century used an indeterminate sentencing model, based on considerations of rehabilitation. ${ }^{20}$ Because the consensus view was that each individual had a different potential for rehabilitation, judges did not determine sentences on the basis

20. United States v. Mistretta, 488 U.S. 361, 363 (1988). Because rehabilitation times differ for each prisoner, judges must make a determination about each prisoner's potential for rehabilitation and sentence accordingly. Id. This presupposes that the sentencing judge will be able to ascertain which defendants require more time in prison to be rehabilitated. 
of the crime committed. Instead, Congress gave judges a great degree of discretion to impose sentences within wide statutory ranges. ${ }^{21}$

Many critics disapproved of the indeterminate system, because the large amount of discretion given to sentencing judges led to serious disparities in sentences for similar crimes. ${ }^{22}$ For example, Marvin E. Frankel, former United States District Judge for the Southern District of New York, wrote that "those of us whose profession is the law must not choose any longer to tolerate a regime of unreasoned, unconsidered caprice for exercising the most awful power of organized society, the power to take liberty and ... life by process of what purports to be law."23

Responding to such criticism, in 1983 the United States Senate issued a report referring to the "outmoded rehabilitation model" and noting that the current system was not furthering the goal of rehabilitation. ${ }^{24}$ The report found that the indeterminate system had two main flaws: first, the sentences imposed upon similarly situated offenders varied greatly; ${ }^{25}$ and second, the amount of jail time an offender would receive was too unpredictable. ${ }^{26}$ Both flaws made the indeterminate sentencing system unjust.

\section{B. The Process of Change}

Reform of the indeterminate system started in the $1970 \mathrm{~s}^{27}$ In 1976, California abolished its parole board and established statutory presumptive sentences for all serious offenses. ${ }^{28}$ In the eight years between 1976 and 1984, more than twenty states followed California in revising their sentencing laws. ${ }^{29}$ These revisions con-

21. Id. at 364 .

22. Id. at 365 .

23. Marvin E. Frankel, Lawlessness in Sentencing, 41 U. CIN. L. REv. 1, 2 (1972).

24. S. REP. No. 225,98 th Cong., 1st Sess. 38 (1983), reprinted in 1984 U.S.C.C.A.N. $3182,3221$.

25. Id.

26. Id.

27. See SANDRA SHANE-DuBow ET Al, SENTENCING REFoRm in the UNITED STATES: HISTORY, CONTENT, AND EFFECT (National Inst. of Justice 1985) (state-by-state survey); Michael H. Tonry, Real Offense Sentencing: The Model Sentencing and Correction Act, 72 J. Crim. L. \& Criminology 1550, 1551 (1981).

28. California Uniform Determinate Sentencing Act, ch. 1139, § 273, 1976 Cal. Stat. 5140 (codified at CAL. PENAL CODE $\S 1170$ (West 1991)).

29. See SHANE-DUBOW ET AL,, supra note 27. 
sisted of abolishing parole, narrowing the role of judicial discretion, and creating sentencing guidelines. ${ }^{30}$

In 1984 the United States Congress passed the Sentencing Reform Act of $1984 .^{31}$ The Act had five stated goals:

1. To promote certainty in sentencing by mandating chargeoffense sentencing ${ }^{32}$ and by eliminating parole ${ }_{3}^{33}$

2. To require sentencing judges to state the reasons for their decisions, so that appeal would be possible; ${ }^{34}$

3. To achieve proportionality in sentencing; ${ }^{35}$

4. To reduce the amount of disparity in sentences of similarly situated offenders, ${ }^{36}$ and

5. To establish a sentencing commission that would promulgate sentencing guidelines. ${ }^{37}$

Congress mandated a guidelines system with the hope that it would reduce the existing sentencing disparities yet allow sentencing judges a certain measure of flexibility to compensate for individual circumstances. ${ }^{38}$ The Guidelines, therefore, present a mix of the determinate and indeterminate sentencing systems.

The new guidelines system rejects rehabilitation as a goal of imprisonment. ${ }^{39}$ Instead, the new legislation seeks retribution, education, deterrence, and incapacitation. ${ }^{40}$ Further, the Commission made the Guidelines binding on the courts, ${ }^{41}$ and authorized appellate review of sentencing determinations. ${ }^{42}$

30. See id. at $290-92$.

31. Pub. L. No. $98-473$, ch. 2, 98 Stat. 1987 (1984) (codified principally at 28 U.S.C. $\$ \S 991-998$ (1988)). The Act established the United States Sentencing Commission with instructions to create a Guidelines system that would promote the five goals of the Act. Id. $\S 217($ a), 98 Stat. at 2017-18.

32. S. REP. No. 225 , supra note 24 , at 56 , reprinted in 1984 U.S.C.C.A.N. at 3239 . Charge-offense sentencing mandates a set sentence for each type of crime. Stephen Breyer, The Federal Sentencing Guidelines and the Key Compromises upon Which They Rest, 17 Hofstra L. REv. 1, 9 (1988).

33. Sentencing Reform Act $\S 218(a)(5), 98$ Stat. at 2027 (repealing 18 U.S.C. $\S \S$ $4201-4218$ (1982)); S. REP. No. 225, supra note 24, at 60 , reprinted in 1984 U.S.C.C.A.N. at 3243 .

34. S. REP. No. 225, supra note 24, at 60, reprinted in 1984 U.S.C.C.A.N. at 3243.

35. Id. at 50-52, reprinted in 1984 U.S.C.C.A.N. at 3233-35.

36. Id. at 52, reprinted in 1984 U.S.C.C.A.N. at 3235.

37. Id. at 159-62, reprinted in 1984 U.S.C.C.A.N. at 3342-45.

38. United States v. Mistretta, 488 U.S. 361, 367 (1988).

39. 28 U.S.C. $\S 994(\mathrm{k})$ (1988).

40. 18 U.S.C. $\S 3553(a)(2)$ (1988).

41. Id. $\S 3553(\mathrm{a}),(\mathrm{b})$.

42. Id. $\S 3742(\mathrm{e})$, (f). An appellate court must review sentencing determinations using 


\section{The Guidelines System}

The present system is a matrix that matches a sentencing range with a defendant's offense level. The sentencing judge calculates the offense level by determining the base level of the defendant's crime and then adjusting the level according to special offender characteristics such as the defendant's criminal history and/or acceptance of responsibility. ${ }^{43}$ The amount of punishment, however, cannot exceed the statutory maximum set for the base offense by Congress. ${ }^{44}$ Thus, the Guidelines stand as a fundamental change in sentencing: Although judges are permitted to adjust the sentence levels if they discover reliable information of relevant conduct, they no longer exercise unfettered discretion. ${ }^{45}$

The simplest way to understand the Guidelines is to follow their implementation through another example. Imagine a further adventure of John Doe. Judge Vox Populi convicts Mr. Doe, who has one prior serious conviction, ${ }^{46}$ for money laundering ${ }^{47}$ $\$ 200,000$. At sentencing, the probation officer's presentence report revealed information that $\mathrm{Mr}$. Doe laundered an additional $\$ 175,000$. Further, the defendant admitted at trial that he knew that the $\$ 200,000$ he had admitted laundering had come from the sale of narcotics. steps: ${ }^{48}$

At sentencing, the judge would proceed through the following

1. Find the statute of conviction in the Guidelines' statutory index. The judge will find Money Laundering and Monetary Transaction Reporting under section 2S1.1.

2. Look up the base offense level for the conviction (Level 23). ${ }^{49}$

3. Add "specific offense characteristics." "so

a standard of "clear error" for the findings of fact, and a standard of unreasonableness for the application of the Guidelines.

43. GUIDELINES MANUAL, supra note 2, §§ 3A1.1-3E1.1.

44. United States v. Mistretta, 488 U.S. 361,375 (1989).

45. The Guidelines, however, leave judges the power to determine the reliability of the factual information that guides where on the matrix a defendant's sentence will fall. GUIDELINES MANUAL, supra note 2, § 1B1.4.

46. That is, a conviction with a sentence of imprisonment exceeding thirteen months. Id. $\S 4 \mathrm{~A} 1.1(\mathrm{a})$.

47. 18 U.S.C. $\$ 1956(\mathrm{a})(1)$ (A) (1988).

48. GUIDELINES MANUAL, supra note 2 , § 1B1.1.

49. Id. \& $2 \mathrm{~S} 1.1(\mathrm{a})(1)$.

50. Breyer, supra note 32 , at 6 . 
a. Add three levels because defendant knew that the money came from the sale of narcotics (raising the offense to Level 26). ${ }^{\text {s1 }}$

b. Determine if the laundering of the additional $\$ 175,000$ should be aggregated as "Relevant Conduct" (in this case, yes)..$^{52}$

c. Therefore, add three levels for the amount of money laundered (raising the offense level to Level 29). ${ }^{33}$

4. Determine if any of the adjustments from chapter 3 of the Guidelines apply. They include adjustments for a vulnerable victim or an official victim, abduction of the victim, the defendant's role in the offense, efforts to obstruct justice, acceptance of responsibility, and rules for multiple counts (assume none of these apply). ${ }^{54}$

5. Calculate a criminal history score based on the offender's past conviction record. The Guidelines assign point values depending on the number of prior convictions, and the seriousness of those convictions.ss The sentencing judge then totals the points; the higher the number of points, the more the judge will increase the defendant's sentence. ${ }^{56}$ Here, section 4A1.1 assigns three points for one prior serious conviction. ${ }^{\text {S7 }}$

6. Determine the sentence using the Guidelines matrix..$^{58}$ Here, an offense level of 29 , with three points for the prior conviction, yields a range of $97-121$ months in prison. ${ }^{59}$

7. Impose the Guideline sentence; or if the court finds unusual factors, depart and impose a non-Guidelines sentence, ${ }^{60}$ in which case the judge must list reasons for the departure, ${ }^{61}$

51. GưIDELINES MANUAL, supra note $2, \S 2 S 1.1(\mathrm{~b})(1)$.

52. Id. \& 1B1.3. Assume that the laundering of the $\$ 175,000$ is found to be relevant conduct under "same course of conduct." Id. \&1B1.3(a)(2).

53. See id. \& 2S1.1(b)(2)(D).

54. Id. §§ 3A1.1-3E1.1.

55. Id. § $4 \mathrm{~A} 1.1$.

56. The sentence, however, may not exceed the statutory maximum set for the base offense by Congress. United States v. Mistretta, 488 U.S. 361, 375 (1989).

57. GUIDELINES MANUAL, supra note 2, § 4A1.1(a).

58. Id. § $5 \mathrm{~A}$.

59. Id.

60. 18 U.S.C. $\S 3553(\mathrm{~b})$ (1988). This provision adds an element of indeterminacy to the Guidelines. The limited usefulness, however, and the restrictions on a judge's use of it (listing the acceptable reasons for departure, and allowing appellate review of the reasonableness of the departure) minimize its indeterminate effect.

61. Id. $\S 3553(\mathrm{c})$. 
and then the appellate court may review the reasonableness of the departure. ${ }^{62}$

The Guidelines provide sentencing courts with a clear formula for each defendant's sentence. The system prescribes that sentencing judges determine whether certain facts exist, and the Guidelines formulas mandate sentences accordingly. ${ }^{63}$ This added reliance on the factfinding role of sentencing courts creates an enhanced concern for the reliability and accuracy of the information considered by the judge. ${ }^{64}$ Although courts have always questioned the reliability of factual determinations at sentencing, ${ }^{65}$ the added importance of factfinding under the Guidelines has recently highlighted this issue. ${ }^{65}$

\section{The Courts Have Their SAY}

One aspect of courts' concern with the reliability of factfinding during sentencing has been their evaluation of whether confrontation rights apply at sentencing. The United States Supreme Court first addressed this issue in Williams v. New York, ${ }^{67}$ in which the Court found that Fourteenth Amendment confrontation rights did not apply under the indeterminate sentencing system. ${ }^{6}$ Another pre-Guidelines case, Specht v. Patterson, ${ }^{69}$ limited Williams. Specht held that Colorado's sentencing system was different enough from the federal indeterminate system to implicate confrontation rights under the Fourteenth Amendment's Due Process Clause. ${ }^{70}$ The case of United States $v$. Fatico ${ }^{71}$ then extended the analysis of the

62. Id. § 3742(e).

63. These factual determinations, coupled with the judge's appointment of the exact sentence within the prescribed range, provide elements of indeterminacy in the Guidelines that are carried over from the former sentencing system. The judge, however, may not ignore factual determinations once they are found, and must invoke the Guidelines sentences for those factual situations; he may only then adjust for spccific offender characteristics and departures. GUIDELINES MANUAL, supra note $2, \S 1$ 1B1.1(h), (i) \& cmt. n.2.

64. See United States v. Kikumura, 918 F.2d 1084, 1101 (3d Cir. 1990) (stating that the factfinding underlying a departure must be supported by clear and convincing evidence when the magnitude of the departure is great).

65. See, e.g., Williams v. New York, 337 U.S. 241, 244 (1949).

66. See, e.g., Kikumura, 918 F.2d at 1101.

67. 337 U.S. 241 (1949).

68. Id. at 251 .

69. 386 U.S. 605 (1967).

70. Id. at 608.

71. 579 F.2d 707 (2d Cir. 1978). 
confrontation rights issue by analyzing the Confrontation Clause of the Sixth Amendment. ${ }^{2}$

After the Sentencing Reform Act of 1984, the courts began reevaluating whether confrontation rights should apply at sentencing. United States $v$. Castellanos, ${ }^{73}$ in the Eleventh Circuit, first raised the issue under the Guidelines; however, the court ultimately found the argument for extending confrontation rights unpersuasive. Similarly, the Tenth Circuit in Beaulieu v. United States $^{74}$ also held that confrontation is not necessary at sentencing. Shortly thereafter, the District Court for the District of Maine, in United States v. Luna, ${ }^{75}$ followed Beaulieu. The Eighth Circuit, however, found in United States v. Fortier ${ }^{76}$ that the Confrontation Clause does apply at sentencing. The Fortier analysis was rejected by the Third Circuit in United States v. Kikumura;" however, the Sixth Circuit for a short time adopted the Fortier reasoning in United States $v$. Silverman. ${ }^{78}$

\section{A. Cases Before the Federal Sentencing Guidelines}

In Williams $v$. New York, ${ }^{79}$ the jury recommended life imprisonment for Williams, convicted of first-degree murder. ${ }^{80}$ At sentencing, the trial judge considered information about Williams's previous record. Williams, however, never confronted or crossexamined the witnesses against him on that subject. ${ }^{81}$ Then, after considering all the relevant information, the judge sentenced Williams to death. ${ }^{82}$ Williams challenged his sentence, claiming that due process mandated that he have the opportunity to confront the witnesses against him. ${ }^{83}$

72. Id. at 713-14. Fatico ultimately decided under the Confrontation Clause not to apply confrontation rights to sentencing.

73. 882 F.2d 474 (11th Cir. 1989), vacated, 904 F.2d 1490 (11th Cir. 1990).

74. 893 F.2d 1177, 1180-81 (10th Cir.), cert. denied, 110 S. Ct. 3302 (1990).

75. 734 F. Supp. 552,554 (D. Me. 1990).

76. 911 F.2d 100, 103 (8th Cir. 1990), overnuled by United States v. Wise, 976 F.2d 393 (8th Cir. 1992).

77. 918 F.2d 1084, 1103 n.19 (3d Cir. 1990).

78. 1991 WL 179608 (6th Cir. Sept. 17, 1991), vacated, 976 F.2d 1502 (6th Cir. 1992) (en banc).

79. 337 U.S. 241 (1949).

80. Id. at 242.

81. Id. at 243.

82. Id. at 242 .

83. Id. at 245 . 
In its analysis of the case, the Supreme Court explained the philosophy of the indeterminate sentencing system. ${ }^{84}$ The Court stated that not every offense is a legal category. Individuals convicted of the same offense should not always be given identical punishment; ${ }^{85}$ instead, the philosophy of individualized sentencing, which distinguishes, among other things, between first-time and repeat offenders, will necessarily have to take into account information from nonjudicial agencies. ${ }^{86}$

Because "[r]etribution is no longer the dominant objective" and "[r]eformation and rehabilitation of offenders have become important goals," the Court determined that the sentencing judge must consider a wide range of information. ${ }^{87}$ Therefore, allowing cross-examination in open court of all the witnesses in a presentence report is impractical, if not impossible. "The due-process clause," the Court concluded, "should not be treated as a device for freezing the evidential procedure of sentencing in the mold of trial procedure." ${ }^{89}$ Therefore, although due process does apply at sentencing, it does not guarantee all of the procedural protections it guarantees at trial.

Seventeen years later, in Specht v. Patterson ${ }^{90}$ the Supreme Court interpreted Williams to mean that some sentencing systems require confrontation rights. ${ }^{91}$ The State of Colorado convicted Specht of indecent liberties under a statute that had a ten-year maximum penalty. ${ }^{92}$ However, the trial court sentenced him under the state's Sex Offenders Act for an indeterminate term of from one day to life imprisonment. ${ }^{93}$ The act stipulated that it should be applied if the trial court judge believed that the convicted person would pose a physical threat to the public, or was a habitual offender and was mentally ill. ${ }^{94} \mathrm{~A}$ psychiatrist examined Specht, and filed a report with the trial court judge. ${ }^{95}$ Although the case

\footnotetext{
84. Id. at $246-49$.

85. Id. at 247.

86. Id. at 248.

87. Id.

88. Id. at 250.

89. Id. at 251 .

90. 386 U.S. 605 (1966).

91. Id. at 610 .

92. Id. at 607.

93. Id.

94. Id.

95. Id. at 608 .
} 
does not explicitly state so, the report must have suggested that Specht was a physical threat to the public, because the range of the sentence included life imprisonment. ${ }^{96}$ However, the judge did not hold a hearing on the psychiatrist's report. ${ }^{97}$

On appeal, Specht argued that the trial court had denied him due process under the Fourteenth Amendment, because he had no opportunity to challenge the psychiatric report. ${ }^{98}$ Although it adhered to the Williams decision, the Supreme Court declined to apply Williams in this "radically different situation."

Writing for the Court, Justice Douglas observed that the Sex Offenders Act did not make the commission of a specified crime the basis for sentencing. ${ }^{100}$ Instead, the Colorado system made one conviction the basis for starting another proceeding. ${ }^{101}$ The Court found Specht to be like those cases that arise under recidivist statutes-in which an habitual crime issue is "a distinct issue."102 Douglas concluded that the Colorado system differed significantly from the indeterminate system used in Williams because it called for the sentencing court to make a determination on an issue that was separate from those decided at trial. ${ }^{103}$ Based on this conclusion, the Court-required confrontation to fulfill due process. ${ }^{104}$

The Second Circuit further interpreted Williams in United States v. Fatico, ${ }^{105}$ holding that confrontation rights would be impractical at sentencing. The District Court for the Eastern District of New York's opinion in this case, ${ }^{106}$ written by Judge Weinstein, is especially important because it signaled the first consideration of the Confrontation Clause of the Sixth Amend-

\footnotetext{
96. $I d$.

97. Id.

98. Id.

99. Id.

100. Id.

101. Id.

102. Id. at 610 (citing Graham v. West Virginia, 224 U.S. 616, 625 (1911)).

103. Id.

104. Id. at 611.

105. 579 F.2d 707 (2nd Cir. 1978). Carmine and Daniel Fatico were indicted on charges related to several truck hijackings. Id. at 709 . They pled guilty to, and the court convicted them of, one count of conspiracy to possess a quantity of furs stolen from a foreign shipment. Id. As a result of their guilty pleas, they faced a maximum penalty of five years imprisonment and a $\$ 10,000$ fine under 18 U.S.C. $\$ 371$. Id.

106. 441 F. Supp. 1285 (E.D.N.Y. 1977), rev'd, 579 F.2d 707 (2d Cir. 1978).
} 
ment, instead of only the Due Process Clause of the Fourteenth Amendment, in the context of sentencing. The Second Circuit, however, never separately analyzed the case on Sixth Amendment grounds. Instead, the court declared the Sixth Amendment issue moot, finding that the Confrontation Clause protects the same rights as the Due Process Clause of the Fourteenth Amendment. ${ }^{107}$ Thus, as Williams had already determined that the Due Process Clause did not extend confrontation rights to sentencing, the Second Circuit reversed the district court. ${ }^{108}$

Before sentencing, the Faticos objected to the inclusion in the presentence reports of statements identifying them as members of the Gambino organized crime family. ${ }^{109}$ The government offered corroborating evidence, but would not produce the informant for fear that he would be harmed. ${ }^{110}$ The defendants maintained that the court denied their rights under the Due Process and Confrontation Clauses due to the refusal of the government to disclose the identity of the informant. ${ }^{111}$

Judge Weinstein acknowledged the Williams holding requiring different evidentiary rules governing trial and sentencing procedures. ${ }^{112} \mathrm{He}$ noted, however, that the Williams decision allowed the sentencing judge to consider as much information as possible to determine the defendant's character and background. ${ }^{113}$ Further, he cited growing concern that the standard for reliability of testimony was not high enough, ${ }^{114}$ and concluded that "[t]here has been a clear drift away from the absolute no-due-process-at-sentence position some have read into Williams."115

In discussing of the Confrontation Clause, Judge Weinstein first emphasized the importance of the right of confrontation ${ }^{116}$ and of the sentencing process. ${ }^{117}$ Next, he outlined three rudimentary principles of the Confrontation Clause. First, the Confron-

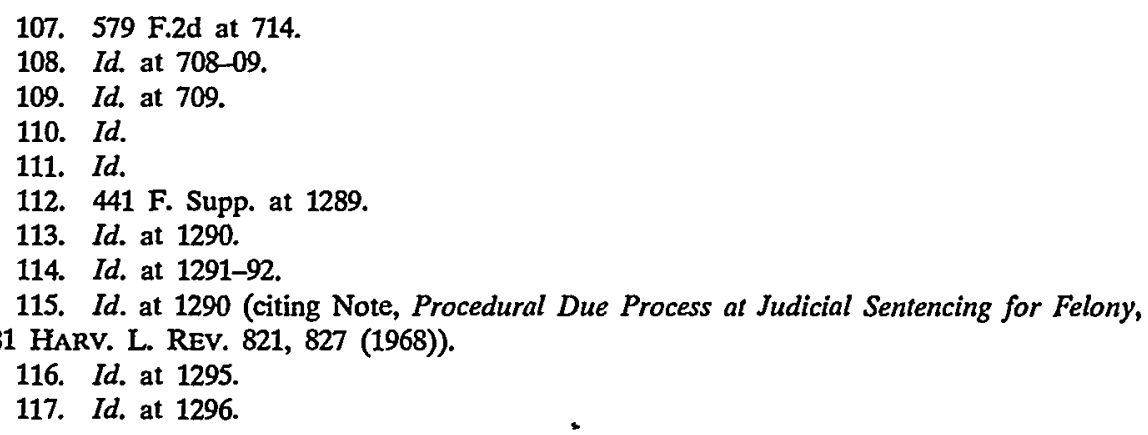


tation Clause and the hearsay rules, although generally construed to protect similar values, are not congruent. ${ }^{118}$ Second, the Confrontation Clause imposes at least a good faith effort on the government to produce the witness. ${ }^{119}$ Lastly, the Framers designed the Clause to protect against "flagrant abuses, anonymous accusers, and absentee witnesses." "120

The court concluded from these principles that, "the government cannot affirmatively prevent the defendant from examining under oath a declarant when the declarant's knowledge is offered by the government (1) at a critical stage of the criminal process, (2) as to crucial information that (3) directly affects a substantial liberty interest of the defendant."121 As he considered that this requirement would not burden the sentencing process, and would safeguard the defendant's constitutional right of confrontation under the Sixth Amendment, ${ }^{122}$ Judge Weinstein held that the sentencing judge could not rely on the informant's testimony unless he was subject to meaningful cross-examination. ${ }^{123}$

In its consideration of the Faticos' appeal, ${ }^{124}$ the Second Circuit reversed the district court's ruling ${ }^{125}$ without separately analyzing the Confrontation Clause issue. Judge Oakes, who authored the majority opinion, followed Williams. He wrote, "it was not a denial of due process in sentencing to rely on information supplied by witnesses whom the accused could neither confront nor crossexamine." 126 The court agreed with the Williams decision that if it extended confrontation rights, ${ }^{127}$ sentencing would become "impractical if not impossible."128

Furthermore, Judge Oakes decided that the Confrontation Clause issue was moot, because both it and the Due Process Clause "are directed at ensuring the fairness of criminal proceed-

118. Id.

119. Id. at 1297.

120. Id. (quoting California v. Green, 399 U.S. 149 (1970)).

121. Id.

122. Id

123. Id. at 1299

124. 579 F.2d 707 (2d Cir. 1978).

125. Id. at 708-09.

126. Id. at 711.

127. The Williams decision was based upon the Fourteenth Amendment's Due Process Clause, but the district court in Fatico used the Williams reasoning to address the Confrontation Clause issue. Id. at 710-12.

128. Id. at 712 . 
ings by defining the situations in which confrontation by crossexamination inust be afforded a defendant."129 Because the court decided that the two constitutional protections are substantially similar, it interpreted the Williams rejection of confrontation under the Due Process Clause to apply also to the Confrontation Clause. ${ }^{130}$

B. Cases After the Imposition of the Federal Sentencing Guidelines Williams, Specht, and Fatico all predate the Sentencing Reform Act of 1984. Williams held that due process confrontation did not apply at sentencing; Specht followed Williams, allowing confrontation rights only in radically different sentencing systems; and Fatico extended these analyses to also reject-confrontation at sentencing under the Confrontation Clause. Since the Sentencing Reform Act, however, there has been renewed discussion of whether Sixth and Fourteenth Amendment confrontation rights should apply at sentencing under the Guidelines. United States $v$. Castellanos $^{131}$ was the first case to raise the issue. Castellanos objected to the sentencing judge's consideration of information from the trial of one of Castellanos's co-defendants. ${ }^{132}$

On December 3, 1987, Alejandro Castellanos and a co-defendant transported nine ounces of cocaine from Miami to Tampa, Florida. ${ }^{133}$ In Tainpa, Castellanos witnessed an exchange of the cocaine, of which a DEA agent subsequently took possession. ${ }^{134}$ The sentencing judge relied on information contained in the presentence report, and found that Castellanos's offense involved over five kilograins of cocaine. ${ }^{135}$

A panel of the Eleventh Circuit theorized that it is proper for a sentencing judge to use evidence presented at the defendant's own trial. ${ }^{136}$ However, when the judge relies on evidence obtained from the trial of another, the defendant has no opportunity to cross-examine, make objections to evidence, or put on his own

129. Id. at 714 .

130. Id.

131. 882 F.2d 474 (11th Cir. 1989), vacated, 904 F.2d 1490 (11th Cir. 1990) (en banc).

132. 882 F.2d at 476.

133. Id. at 475 .

134. Id.

135. Id. at 476 .

136. Id. at $476-77$. 
case. ${ }^{137}$ Therefore, the court ruled that the evidence obtained at a co-defendant's trial should be excluded at Castellanos's sentencing. ${ }^{138}$

On rehearing en banc, however, the Eleventh Circuit vacated its earlier decision. ${ }^{139}$ In his second opinion, ${ }^{140}$ Judge Tjoflat more fully described Castellanos's objection. Castellanos challenged his sentence on due process grounds, arguing that the Guidelines had blurred the distinction between conviction and sentence, therefore requiring more stringent due process standards at sentencing. ${ }^{141}$ Castellanos based this contention on the fact that a defendant may be convicted of a lesser offense under the "beyond a reasonable doubt" standard of proof, but sentenced for a more serious offense without the safeguard of the higher burden of proof. ${ }^{142}$

Judge Tjoflat explained his earlier opinion to mean only that a sentencing court must follow the procedural safeguards in the Guidelines. These safeguards guarantee the defendant a right to respond to information under consideration. ${ }^{143}$ Also, the second opinion recognized that the current system has not changed to a pure determinate system, because there is still some room for departure at sentencing. ${ }^{144}$ Because the current system still has elements of indeterminacy, the pre-Guidelines law on due process rights at sentencing should apply. ${ }^{145}$

Prior to the Eleventh Circuit having reached its second opinion in Castellanos, the Tenth Circuit had found the first opinion unpersuasive in United States v. Beaulieu. ${ }^{146}$ The Beaulieu court had held that confrontation is not required at sentencing, but the judge must find information to be reliable before considering it. ${ }^{147}$ Beaulieu pleaded guilty in district court to one count of conspiracy to manufacture amphetamines. ${ }^{148}$ The sentencing judge relied on

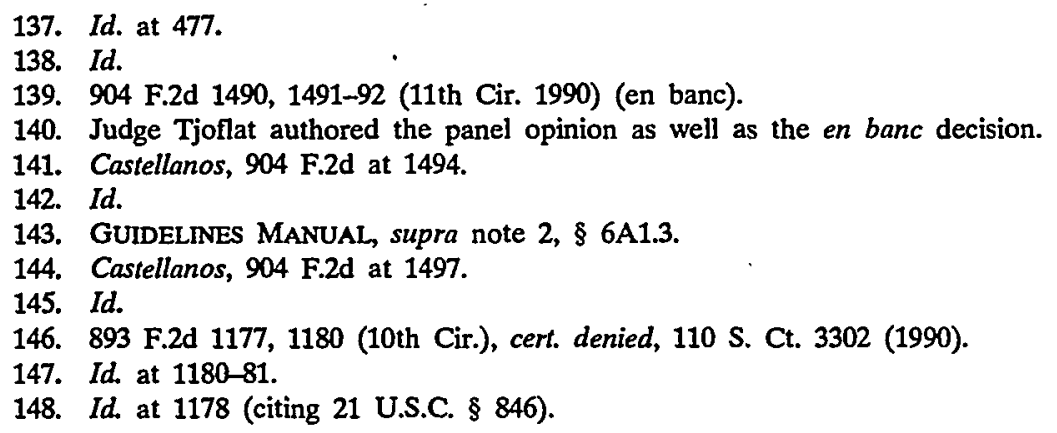


testimony from the trial of Beaulieu's two brothers, also members of the conspiracy, to increase his sentence. ${ }^{149}$ Beaulieu, relying on the first Castellanos decision, challenged the sentencing court's use of testimony from the trial of his brothers. ${ }^{150}$

The Beaulieu decision stated three reasons why there should be no due process confrontation right at sentencing. ${ }^{\text {si }}$ First, a defendant has no absolute right to confront witnesses who have provided information to the court. ${ }^{152}$ Second, the Sentencing Guidelines do not require the exclusion of testimony originating from a separate trial. ${ }^{153}$ Lastly, the Federal Rules of Evidence, which bar much hearsay evidence from the determination of guilt phase of a trial, do not apply at sentencing. ${ }^{154}$ Therefore, the court concluded that reliable hearsay, including testimony from a separate trial, could be used at sentencing. ${ }^{155}$ Neither Beaulieu nor Castellanos, however, based his appeal on Confrontation Clause rights. ${ }^{156}$ Consequently, neither the Tenth Circuit not the Eleventh Circuit addressed that issue. ${ }^{157}$

The district court decision in United States v. Luna ${ }^{158}$ followed the Beaulieu reasoning. The court surmised that the holding in Beaulieu was more convincing and more in line with the Commentary to section $6 \mathrm{~A} 1.3$ of the Guidelines than was the first Castellanos decision. ${ }^{159}$ The Commentary states that information may be used as long as it contains "sufficient indicia of reliability to support its probable accuracy." "160 The court maintained that the Guidelines do not change the sentencing procedure sufficiently

149. Id. at 1179.

150. Id.

151. Id. The case did not discuss the Confrontation Clause of the Sixth Amendment.

152. Id. at 1180.

153. Id. at 1181.

154. Id.; GUIDELINES MANUAL, supra note $2, \S 6 \mathrm{~A} 1.3 \mathrm{cmt}$.

155. Beaulieu, 893 F.2d at 1181.

156. Id. at 1179; Castellanos, 904 F.2d at 1493.

157. Because the first Castellanos decision is unclear about which rights it is discussing, in Beaulieu the Tenth Circuit was unsure whether the Castellanos court grounded its decision in the Due Process Clause of the Fifth Amendment, the Confrontation Clause of the Sixth Amendment, the Sentencing Guidelines, or the Federal Rules of Evidence. Beaulieu, 893 F.2d at 1180 n.4.

158. 734 F. Supp. 552, 554 (D. Me. 1990).

159. Id. at 554.

160. GUIDELINES MANUAL, supra note $2, \S 6 \mathrm{~A} 1.3 \mathrm{cmt}$. (quoting United States v. Marshall, 519 F. Supp. 751 (D. Wis. 1981), affd, 719 F.2d 887 (7th Cir. 1983)). 
such that Williams should be distinguished. ${ }^{161}$. Therefore, a defendant's due process right of confrontation is insufficient to keep a court from using evidence obtained from a proceeding from which the defendant was absent, as long as the reliability of the evidence satisfies the sentencing judge. ${ }^{162}$ Again, the court did not analyze the Confrontation Clause.

The Eighth Circuit, however, did review the Confrontation Clause in the case of United States v. Fortier ${ }^{163}$ in which the court found that the Confrontation Clause does apply at sentencing. Michael Fortier pleaded guilty to one count of possession with intent to distribute 139 grams of cocaine. ${ }^{164}$ At sentencing the judge considered an amount of cocaine in a count to which Mr. Fortier had not pleaded guilty. ${ }^{165}$ Due to the consideration of this additional amount of cocaine, the sentencing judge enhanced Fortier's sentence. ${ }^{166}$ The defendant appealed, arguing that consideration of an additional amount of cocaine, listed in a count to which he had not pleaded guilty, violated his rights under the Confrontation Clause. ${ }^{167}$

Judge Richard Arnold wrote the opinion of the court, and posited that the sentence enhancement was based on multiple hearsay, for which there was no independent finding of reliability. ${ }^{168}$ In the presentence report, the probation officer linked Fortier to 249 grams of cocaine through a report from a special agent. This presentence report stated that a confidential informant had told the special agent that a third person said the drugs belonged to Fortier. ${ }^{169}$ Judge Arnold held that " $\left.t\right]$ he Confrontation Clause requires that the government make its proof in a reliable fashion; the absence of proper confrontation of witnesses calls into question the integrity of the fact-finding process." 170

To test the reliability of individual facts, Judge Arnold advocated the following procedure: If the defendant disputes the facts

161. Luna, 734 F. Supp. at 554.

162. Id.

163. 911 F.2d 100 (8th Cir. 1990), overruled by United States v. Wise, 976 F.2d 393 (8th Cir. 1992).

164. Id. at 101 (citing 21 U.S.C. $\S 841(\mathrm{a})(1)$ ).

165. Id.

166. Id.

167. Id.

168. Id. at 103-04.

169. Id. at 103.

170. Id. 
in the presentence report, the court must state that it is not considering those facts, or make a finding resolving the dispute. This finding must satisfy the Confrontation Clause. ${ }^{171}$ Thus, to consider hearsay at sentencing, the judge must find the declarant unavailable, and that the information has "particularized guarantees of trustworthiness."172

In United States v. Kikumura, ${ }^{173}$ the Third Circuit rejected the Fortier analysis. The court refused to extend Confrontation Clause rights to sentencing, ${ }^{174}$ but did recognize that under the Guidelines the defendant needs more procedural protections than he needed under the indeterminate system. ${ }^{175}$ The Kikumura case involved what was apparently the largest sentence enhancement in absolute or percentage terms since the imposition of the Guidelines. ${ }^{176}$ Kikumura challenged the admissibility at sentencing of hearsay statements made by a confidential informant linking Kikumura to the Japanese Red Army. ${ }^{1 m}$

Judge Edward Becker found the case a prime example of both the utility and danger of determinate sentencing. ${ }^{178}$ According to Judge Becker, if the district court could not have enhanced Kikumura's sentence, then his crimes would not have been adequately punished. ${ }^{179}$ The fairness of the proceeding, however, is called into question when the sentencing judge hears evidence post-trial, with significantly lower procedural protections for the defendant. ${ }^{180}$

171. Id.

172. Id. (quoting Ohio v. Roberts, 448 U.S. 56, 66 (1980)).

173. 918 F.2d 1084 (3d Cir. 1990).

174. Id. at $1102-03$.

175. Id. at 1099.

176. Id. at 1089. Yu Kikumura was convicted of interstate transportation of explosive devices under 18 U.S.C. $\$ 844$ (d), and of passport offenses. 918 F.2d at 1094. His prescribed Guidelines sentencing range was 27 to 33 months in prison. Id. At sentencing, information from a confidential informant was considered, id. at 1096-97, which indicated Kikumura had made three lethal homemade firebombs for a major terrorist bombing on American soil. Id. at 1095-96. The district court departed from the Guidelines, finding that the circumstances of Kikumura's offense were not adequately contemplated by the Sentencing Commission. Id. at 1097. Thus, Kikumura was sentenced to 30 years in prison. Id. at 1098.

177. Id. at 1094.

178. Id. at 1099.

179. Id.

180. Id. 
Judge Becker went on to note that these significantly lower procedural protections at sentencing have been upheld. ${ }^{181}$ For instance, the Constitution does not require trial by jury at sentencing. ${ }^{182}$ Also, the sentencing judge need only establish the facts presented at sentencing by a preponderance of the evidence. ${ }^{183}$ Finally, the Federal Rules of Evidence are not applicable at sentencing. ${ }^{184}$

The court concluded that the convicted criminal is not entitled to the full force of the Constitution's procedural guarantees. ${ }^{185}$ Because the trial judge has already made the determination of guilt or innocence, the less crucial determination, sentencing, is not worth further burdening the trial courts. ${ }^{186}$ In cases such as Kikumura, however, where the sentencing hearing is "a tail which wags the dog of the substantive offense," further procedural guarantees are necessary. ${ }^{187}$

The court proposed two possible solutions to this problem. First, the legislature could more narrowly define the conduct that can be considered for enhanceinent. ${ }^{188}$ Second, courts could raise the level of procedural rights at sentencing so they are closer to those at trial. ${ }^{189}$ Then, Judge Becker concluded that the former solution was not in his judicial power, ${ }^{20}$ and he was unwilling to raise the procedural right of confrontation to a level that would make the Confrontation Clause apply at sentencing. ${ }^{191}$ Instead, he advocated an intermediate standard under which hearsay statements cannot be considered unless they are reasonably trustworthy. ${ }^{192}$

181. Id.

182. Id; see, e.g., Spaziano v. Florida, 468 U.S. 447, 459 (1984).

183. 918 F.2d at 1099; see McMillan v. Pennsylvania, 477 U.S. 79, 91 (1986) (holding that preponderance standard is generally constitutional); United States v. McDowell, 888 F.2d 285, 290-91 (3d Cir. 1989) (holding that the preponderance standard is generally appropriate in guidelines sentencing).

184. 918 F.2d at 1100; see FED. R. EVID. 1101(d)(3).

185. 918 F.2d at 1100 .

186. Id.

187. Id. at 1101 (quoting McMillan, 477 U.S. at 88).

188. Id. .

189. Id.

190. See id. (noting that absent special circumstances, appellate court could not consider an issue that the parties had failed to raise at trial).

191. Id. at 1102 .

192. Id. at 1103 . Because the commentary to $\S 6 \mathrm{~A} 1.3$ of the Guidelines already required reliable information, Becker's intermediate standard merely asks judges to use 
In United States $v$. Silverman, ${ }^{193}$ the Sixth Circuit weighed Fortier against Kikumura, and found the former more convincing. ${ }^{194}$ In Silverman, the police seized 52.9 grams of cocaine from Silverman's duffel bag, after a government agent attempted to buy cocaine from him. ${ }^{195}$ The sentencing judge considered information from a confidential informant that linked the defendant to an additional kilogram of cocaine. ${ }^{106}$ Silverman appealed the sentencing determination, contending that the hearsay evidence at issue was inadmissible because only evidence admissible at trial should be considered. ${ }^{197}$ Silverman never made specific reference to the Confrontation Clause. ${ }^{198}$

Judge Merritt, writing the majority opinion in Silverman, explained that the Sentencing Guidelines have revolutionized sentencing and elevated factfinding to a greater importance. ${ }^{199}$ This change is so significant that it renders pre-Guidelines law moot, and requires a new balancing of procedural guarantees. ${ }^{200}$ Relying on Specht v. Patterson, ${ }^{201}$ Judge Merritt found that when a sentencing system differs from the pre-Guidelines system enough, Williams no longer applies. ${ }^{202}$ The nature of the Sentencing Guidelines makes sentencing adversarial in much the same way that the Colorado system in Specht did, thus creating a system substantially different from the pre-Guidelines indeterminate system. ${ }^{203}$ This difference creates the need for the Confrontation Clause to resolve disputed facts that "have a measurable effect on the applicable punishment." "204

higher standards of reliability.

193. 1991 WL 179608 (6th Cir. Sept. 17, 1991), vacated, 976 F.2d 1502 (6th Cir. 1992) (en banc).

194. See id. at *8-9.

195. See id. at $* 13$ (Wellford, J., dissenting). Subsequently, Silverman pleaded guilty to possession with intent to distribute cocaine. Id. at $* 2$ (citing 21 U.S.C. § 841(a)(1)).

196. Id. at *3. At an evidentiary hearing, a DEA agent testified that a confidential informant told authorities that he and others had become indebted to Silverman aftcr he advanced them a kilogram of cocaine. $I d$. The agent also testified that a co-conspirator corroborated the informant's information. Id. The sentencing court found the information admissible as relevant conduct, GUIDELINES MANUAL, supra note 2, §1B1.3(a)(2), and aggregated the drug amounts. 1991 WL 179608 , at *3.

197. 1991 WL 179608 , at *4.

198. Id.

199. Id. at *8.

200. See id. at $* 7-8$.

201. 386 U.S. 605 (1966).

202. 1991 WL 179608 , at *8-9.

203. Id.

204. Id. at *9 (citation omitted); see GUIDELINES MANUAL, supra note 2, 6 A1.3 
Judge Wellford, dissenting in Silverman, argued that there was no Confrontation Clause issue. Judge Wellford contended that Silverman did not appeal based on the Confrontation Clause, that the majority merely created the issue in order to adopt the holding of Fortier. ${ }^{205}$ He further argued that, even if the Confrontation Clause were at issue, the imposition of the Guidelines would not make Williams irrelevant. ${ }^{206}$ According to Judge Wellford, "[t]here is simply no analogy to the situation under state law in Specht and the panoply of due process protection afforded these federal defendants at their sentencing hearings." ${ }^{2007}$ Wellford also distinguished Fortier from Silverman, citing Fortier's unusual triple hearsay fact situation. ${ }^{208}$

This decision, however, has since been vacated. The Sixth Circuit has held a rehearing en banc of Silverman. ${ }^{209}$ The decision reversed the earlier Sixth Circuit opinion, but did not fully address the Confrontation and Due Process Clause issues. ${ }^{210}$ The majority stated that the Guidelines had not sufficiently changed the sentencing system so as to require new precedential protections. ${ }^{211}$

In United States $v$. Wise, ${ }^{212}$ the Eighth Circuit considered a similar argument. In that case, James Wise appealed a thirty-two month sentence that he received after pleading guilty to two counts of counterfeiting. ${ }^{213}$ Wise argued that the district court violated his due process rights when it did not allow him to call a witness at sentencing. ${ }^{214}$ The court, however, transformed that argument into a Confrontation Clause issue. ${ }^{215}$

Judge Arnold, writing for the majority, held that "[i]t was error to base findings of fact on the probation officer's hearsay testimony without undertaking the Confrontation Clause analysis

cmt.

205. 1991 WL 179608 , at $* 12, * 15$ (Wellford, J., dissenting).

206. See id. at $* 23$.

207. Id.

208. See id. at $* 25 \& \mathrm{nn}$. $6-7$. There is, however, no evidence in the Fortier opinion that it was intended to be linited specifically to triple hearsay fact situations.

209. United States v. Silverman, 976 F.2d 1502 (6th Cir. 1992) (en banc).

210. Id.

211. Id. at 1507-08.

212. 923 F.2d 86 (8th Cir. 1991), vacated, 976 F.2d 393 (8th Cir. 1992) (en banc).

213. Id.

214. Id.

215. Id. 
required by United States $v$. Fortier."216 One judge concurred with the result, but only because he believed Fortier compelled him to do so. ${ }^{217}$ Another judge dissented, arguing that the court should follow Kikumura. ${ }^{218}$

The Eighth Circuit, on its own initiative, held a rehearing en banc. ${ }^{219}$ Wise was reversed, but the majority's opinion gave equally inadequate consideration to the Due Process and Confrontation arguments. The court held that because the Guidelines had not "so transformed the sentencing phase that it constitute[d] a separate criminal proceeding." 200

From Williams to Wise the courts have analyzed the issue of confrontation rights at sentencing in a piecemeal fashion. No court has clearly separated the rights offered by the Sixth Amendment and those offered by the Fourteenth Amendment and conducted an in-depth examination of whether these rights should apply at sentencing. When these rights are analyzed separately, their protections mandate confrontation rights at sentencing.

\section{ReAsoning Through the RUbBle}

Confrontation rights should be extended to sentencing for two reasons. First, the Fifth and Fourteenth Amendments should be interpreted to require confrontation to ensure due process. The test enunciated by the Supreme Court in Mathews $v$. Eldridge ${ }^{21}$ indicates that to ensure due process at sentencing, confrontation is necessary. Second, the Confrontation Clause of the Sixth Amendment should apply to sentencing. The text of the Sixth Amendinent and the manner in which the courts have interpreted the Amendment show that the Confrontation Clause applies under the Guidelines.

\section{A. Due Process}

The courts have required due process at sentencing ever since the Williams decision. ${ }^{22}$ Williams and Specht conceded that due

\footnotetext{
216. Id. at 87.

217. Id. (Wollman, J., concurring).

218. Id. (Gibson, J., dissenting).

219. 976 F.2d 393 (8th Cir. 1992) (en banc).

220. Id. at 401 .

221. 424 U.S. 319, 335 (1976).

222. Williams v. New York, 337 U.S. 241 (1949).
} 
process applies at sentencing, but held that under the indeterminate sentencing system due process did not require confrontation. ${ }^{23}$ Morrissey v. Brewer, ${ }^{224}$ however, held that due process rights change when surrounding circumstances change. ${ }^{225}$ The Court in Morrissey stated, "due process is flexible and calls for such procedural protections as the particular situation demands." ${ }^{226}$ Because the sentencing system has changed significantly from the indeterminate system, the Guidelines require a new due process analysis.

Although not a sentencing case, Mathews v. Eldridge ${ }^{27}$ sets forth a three-part test to identify the requirements of due process. The first prong of this test assesses the private interest affected by official action. ${ }^{228}$ Second, the test inquires as to the risk of erroneous deprivation of the private interest. ${ }^{229}$ Last, the Mathews test evaluates the Government's interest that will be affected. ${ }^{230} \mathrm{Un}$ der this test, due process requires the right to confrontation at sentencing under the Guidelines.

1. The Private Interest. The changes in the sentencing system place defendants' liberty interests in jeopardy. United States $v$. Mistretta $^{21}$ measured the impact of the newly created Guidelines on individuals' liberty interests. On appeal, Mistretta challenged the constitutionality of the Guidelines, contending that Congress had created the U.S. Sentencing Commission in violation of the separation of powers principle and that it had delegated excessive authority to the Commission to structure the Guidelines. ${ }^{232}$

The Supreme Court rejected both arguments. Justice Blackmun, writing for the majority, held that Congress did not del-

223. Id. at 245-51; Specht v. Patterson, 386 U.S. 605, 608 (1967).

224. 408 U.S. 471 (1972).

225. Id. at 481 .

226. Id.

227. 424 U.S. 319 (1975).

228. Id. at $335-39$.

229. Id. at $335,339-47$.

230. Id. at $335,347-48$.

231. 488 U.S. 361 (1989). The trial court held Mistretta under indictment on three counts related to the sale of cocaine. Id. at 370 . He pleaded guilty to a conspiracy to distribute count, 21 U.S.C. $\S 846(b)(1)(B)(1988)$, was sentenced under the Guidelines to 18 months of imprisonment, and filed a notice of appeal to the Eighth Circuit. Id. 370-71. Petition for certiorari was granted by the Supreme Court before judgment on the appeal. Id. at 371 .

232. Mistretta, 488 U.S. at 371 . 
egate excessive power to the Commission. ${ }^{233}$ The Court also held that the Guidelines did not violate the separation of powers principle by placing the Commission in the Judicial Branch or by allowing the President to appoint the members of the Commission and remove them for cause. ${ }^{234}$ The majority recognized and spelled out the important differences between the old indeterminate system and the Guidelines ${ }^{235}$ noting that rehabilitation is no longer the goal of sentencing, ${ }^{236}$ and that Congress had decided that rehabilitation is no longer a good reason to sentence people, because the rehabilitative effects of our prison system are questionable at best. $^{237}$

Justice Blackmun also pointed out that all sentences are, for the most part, determinate under the Guidelines. ${ }^{233}$ Sentencing judges can only depart from the Guidelines in a few discrete circumstances. ${ }^{239}$ The Sentencing Commission's Guidelines are binding on the courts ${ }^{240}$ and provide for appellate review of sentences issued under them. ${ }^{241}$ Appellate courts can reverse sentencing determinations only if they find them clearly erroneous. ${ }^{242}$

Justice Scalia's dissent found the changes in sentencing even more radical than the majority did. He wrote that the Guidelines "have the force and effect of laws, prescribing the sentences criminal defendants are to receive. ${ }^{243}$ Thus, Justice Scalia believed that the Guidelines are unconstitutional, as Congress cannot create an agency whose sole function is to make laws. ${ }^{24}$ To back up his argument, Justice Scalia pointed to substantive decisions made by the Commission, including decisions to increase substantially the average sentences for white-collar crimes such as public corruption, antitrust violations, and tax evasion. ${ }^{245}$

233. Id. at 379.

234. Id. at 384 .

235. Id. at $367-68$.

236. Id. at 367.

237. Id. at 366 .

238. Id.

239. Id.

240. Id.

241. Id.

242. See, e.g., United States v. Rodriguez-Gonzalez, 899 F.2d 177, 182 (2d Cir.), cert. denied, 111 S. Ct. 127 (1990).

243. Mistretta, 488 U.S. at 413 (Scalia, J., dissenting).

244. Id. at 419-22. Congress can delegate the authority to create regulations necessary to enforce a law, but cannot delegate the authority to make the law itself. Id. at 417-19.

245. Id. at $413-14$. 
Justice Scalia further pointed out that the contention that the Guidelines merely narrow the statutorily prescribed sentence range is misleading. ${ }^{246}$ Because the "[s]tatutorily permissible sentences for particular crimes cover as broad a range as zero years to life,"247 Congress effectively allowed the Commission to determine its own "statutory" maximums and minimums. ${ }^{248}$

Both opinions in Mistretta pointed out that the changes in the structure of the sentencing system have exposed defendants to a greater potential for deprivation of their liberty interests. Now that Congress has expanded the statutorily prescribed maximums and minimums, a defendant's liberty is in greater jeopardy. Because the range between the statutory minimum and maximum can be so large, adjustments for reliable relevant conduct may be so great that the sentencing determination becomes "the tail that wags the dog" of the substantive offense. United States $v$. Kikumura ${ }^{249}$ is an example of the defendant's disproportionate liberty interest at sentencing, compared to the liberty interest at stake at trial. Because the sentencing judge determined that information concerning relevant conduct was reliable, he increased Kikumura's jail time from the Guidelines maximum of 33 months to 30 years. ${ }^{250}$ Kikumura thus received more than twenty-seven additional years in prison. Such a tenfold increase in jail time highlights the extent to which a defendant's liberty interests are in jeopardy at sentencing.

2. The Risk of Erroneous Deprivation. The Kikumura decision recognized the unfairness that may result from the combination of post-trial testimony and limited protections for the defendant. First, because confrontation does not exist at sentencing, and second, because the parties must prove sentencing facts under the Guidelines only by a preponderance of the evidence, the risk of erroneous deprivation of the defendant's liberty interest is quite high. These two factors, combined with the appellate courts' in-

246. Id. at 414-15. Congress imposes maximums and minimums for each federal crime. These mandates are separate from the Guidelines, but operate to restrict the range of sentence that a judge's use of the Guidelines may produce. Id. at 375 .

247. Id. at 413 (citing 18 U.S.C. $\S 1201$ (1982 ed. and Supp. IV) (kidnapping)).

248. Id.

249. 918 F.2d 1084 (3d Cir. 1990).

250. Id. at 1097-98 (basing this substantial deviation from the Guidelines on several aggravating factors). 
ability to reverse sentencing determinations unless they are clearly erroneous, ${ }^{251}$ create a system with too great a risk of erroneous deprivation of the defendant's liberty interest.

Furthermore, leaving the sentencing judge to decide whether information is reliable also lowers the protection against false information being used against a defendant. Because sentencing determinations cannot be reversed unless clearly erroneous under the Guidelines, very few determinations of reliability will be overturned. Allowing the sentencing judge to make determinations as to the reliability of sentencing information is contrary to the Guidelines' goals of certainty and reduced disparity. ${ }^{252}$ This determination of reliability by the sentencing judge is one of the indeterminate aspects of the Guidelines. Although the Guidelines are mostly determinate, this element of indeterminacy concerning the reliability of evidence makes the system the worst of both worlds. Judges are prescribed to give the sentences that result from the Guidelines matrix, yet defendants and prosecutors cannot predict the results of the sentencing judge's factual determinations.

3. The Government's Interest. The government's main interest is in keeping the sentencing system as practical and efficient as possible. The Williams decision indicated that applying confrontation rights to sentencing would greatly reduce the amount of information that judges can rely upon. ${ }^{253}$ Justice Black wrote, "[t]he type and extent of this information make totally impractical if not impossible open court testimony with cross-examination. Such a procedure could endlessly delay criminal administration in a retrial of collateral issues."254 Judge Oakes's decision in Fatico also cited this quotation..$^{25}$

These holdings show that there are a number of facts that the sentencing judge needs to consider. Facts as to criminal history, ${ }^{256}$ relevant conduct, ${ }^{25}$ and the adjustments in chapter 3 of the Guidelines $^{258}$ must be considered. Some facts will not have been

251. United States v. Lanese, 840 F.2d 1291 (2d Cir. 1989).

252. S. REP. NO. 225 , supra note 24 , at 59-60, reprinted in 1984 U.S.C.C.A.N. at $3242-43$.

253. Williams v. New York, 337 U.S. 241 (1949).

254. Id. at 250 .

255. United States v. Fatico, 579 F.2d 707, 711-12 (2d Cir. 1978).

256. GUIDELINES MANUAL, supra note 2, \& 4A1.1.

257. Id. § $1 \mathrm{~B} 1.3$.

258. Id. §§ 3A1.1-3E1.1 (including adjustments for a vulnerable victim or an official 
available at trial, such as those pertaining to obstruction of justice ${ }^{259}$ and acceptance of responsibility. ${ }^{200}$ Further, when defendants plead guilty, very few facts will have been resolved before the sentencing hearing.

Extending confrontation rights will not prove to be impractical, nor will it prohibit these types of facts from being considered. The court in United States v. Silverman" stated that it "should not prove a serious problem for district courts in most cases."262 The Silverman decision recommended a procedure that district courts could follow:

In the cases in which there is a disputed material fact, the government can decide whether it will attempt to prove the fact under the Confrontation Clause. In each such case the government can decide whether it will seek to enhance the sentence otherwise prescribed by the new code by proffering and attempting to prove such disputed facts. Upon receiving the government's proffer, district courts may decide whether the government's proffer of facts-if proved-would constitute grounds requiring an increased sentence. If the district court rejects the proffer as immaterial, it should sentence the defendant on the basis of the undisputed facts of the charged offense, the defendant's criminal history, and any other aggravating or mitigating factor provided for in the code. If the district court decides that the proffered evidence in dispute would constitute grounds for an increased sentence, it should then conduct an evidentiary hearing in accordance with the Confrontation Clause. ${ }^{233}$

Judge Merritt believed that following this procedure would protect defendants' Confrontation Clause rights, with minimal burden on the sentencing courts.

The above system would also solve a problem that prosecutors experience under the Guidelines. Recall the opening hypotheti-

victim, restraint of the victim, role in the offense, efforts to obstruct justice, acceptance of responsibility, and rules for multiple counts).

259. Id. \& 3C1.1.

260. Id. \& 3E1.1.

261. 1991 WL 179608 (6th Cir. Sept. 17, 1991), vacated, 976 F.2d 1502 (6th Cir. 1992) (en banc).

262. Id. at $* 9$.

263. Id. at $* 10$. 
cal. ${ }^{264}$ As illustrated in John Doe's case, the Guidelines severely limit prosecutors' control over what information the judge considers. A prosecutor might bargain for a guilty plea, and later have no control over whether his end of the bargain is upheld. For instance, John's prosecutor could have decided not to present information implicating John in the fifty prior drug sales. However, the probation officer could include the information in the presentence report, regardless of what the prosecutor does.

The system advocated in Silverman allows the prosecutor to limit the amount of information the judge would consider, because the judge would only consider information presented to him by the prosecutor. If the prosecutor struck a bargain with the defendant, then the prosecutor could choose not to present the information at the evidentiary hearing. Also, this system would not prove to be impractical because the number of full trials would actually decrease. Fewer defendants will plead guilty when they find out that their plea cannot guarantee them less jail time. Further, defense attorneys will take cases to full trial where they will be able to cross-examine witnesses against the accused; by cross-examining these witnesses at trial, a defense attorney will have the opportunity to confront evidence that might have a large impact at sentencing. Although applying confrontation to sentencing will increase the number of evidentiary hearings, it also will decrease the number of full trials, saving time and money.

Finally, confrontation at sentencing will further the goals of the Sentencing Reform Act that established the U.S. Sentencing Commission. ${ }^{265}$ Confrontation will effectively promote sentencing certainty, ${ }^{266}$ proportionality, ${ }^{267}$ and a reduction in disparity among similarly situated offenders. ${ }^{263}$ Because rehabilitation is no longer the goal of sentencing, ${ }^{269}$ the government no longer has a stated interest in considering the possibly erroneous information that confrontation will expel.

264. See supra text accompanying notes 1-6.

265. Sentencing Reform Act of 1984, Pub. L. No. 98-473, ch. 2, 98 Stat. 1837 (codified principally at 28 U.S.C. $\$ \S 991-998$ (1988)).

266. S. REP. No. 225, supra note 24, at 56, reprinted in 1984 U.S.C.C.A.N. at 3239.

267. See id. at 50-52, reprinted in 1984 U.S.C.C.A.N. at 3233-35.

268. Id. at 52, reprinted in 1984 U.S.C.C.A.N. at 3235.

269. 28 U.S.C. $\S 994(k)$ (1988). 


\section{B. The Confrontation Clause}

In 1949, when the Supreme Court decided Williams v. New York, ${ }^{270}$ Pointer v. Texas ${ }^{271}$ had not yet incorporated the Confrontation Clause into the Fourteenth Amendment as a right im state prosecutions. The idea of "ordered liberty" under Palko $v$. Connecticut ${ }^{272}$ was still the prevailing view. Therefore, it is not surprising that Williams did not mention the Confrontation Clause. Later cases, because they relied on Williams, also did not fully address this issue. Thus, the issue of whether the Confrontation Clause applies at sentencing under the Guidelines should be considered independent of Williams.

At sentencing, courts have confused the application of the Confrontation Clause and the Due Process Clause of the Fourteenth Amendment. ${ }^{273}$ The analyses of the two Clauses have a common thread: Both consider the defendant's interests that are in jeopardy. The analyses of the two clauses, however, are different. The Due Process Clause considers the risk of erroneous deprivation and the government's interests. The Confrontation Clause, though, does not consider these factors. Although it is clear that the Fourteenth Amendment's guarantee of due process applies to sentencing, it is unclear whether its guarantees include confrontation at sentencing. It is unclear whether the Sixth Amendment's guarantees apply at sentencing, but it is clear that it guarantees confrontation. Under the Confrontation Clause, confrontation rights exist even if the risk of erroneous deprivation is small or if their extension will be impractical for the government. The private interests, however, should be considered to determine that sentencing fits within the Sixth Amendment's definition of when the Clause should apply.

Courts' interpretation of 'the Sixth Amendment's "witness against him" and "criminal prosecutions" clauses need to be overcome to extend the clause to sentencing. Furthermore; the Guidelines commentary does not exclude the Confrontation Clause from sentencing. Courts also need to overcome their conception of the

270. 337 U.S. 241 (1949).

271. 380 U.S. 400 (1965).

272. 302 U.S. 319,325 (1937) (discussing the idea that only some of the protections in the Bill of Rights apply in state proceedings).

273. See, e.g., United States v. Castellanos, 882 F.2d 474 (11th Cir. 1989), vacated, 904 F.2d 1490 (11th Cir. 1990) (en banc). 
guarantees of the Sixth Amendment as trial rights. This Section first addresses the three textual problems. Second, it will advocate that confrontation during sentencing is within the definition of when the Clause should be applied.

\section{Textual Problems.}

a. Informants at sentencing are "witnesses against him."274 The Confrontation Clause of the Sixth Amendment guarantees the defendant the right to confront only the "witnesses against" him. ${ }^{275}$ Critics of the application of the Confrontation Clause at sentencing argue that persons offering information only upon punishment are not "witnesses against" the accused. ${ }^{276} \mathrm{Be}$ cause they do not testify to facts concerning guilt or innocence, their testimony is not subject to the rigors of the Confrontation Clause. The case of Dowdell $v$. United States ${ }^{27}$ supports this position. Dowdell held that the trial judge, the clerk of the court, and the official reporter, were not witnesses against the accused when they supplemented the trial record at sentencing. ${ }^{278}$ The basis of the Supreme Court's decision was that the individuals were not giving information about the defendant's guilt or innocence. ${ }^{279}$ Therefore, the Court did not allow the accused the protection of confrontation rights as to their testimony, provided by a provision in the Philippines Constitution based on the Sixth Amendment. ${ }^{280}$

However, the issue in Dowdell is quite different from that which arises under the Sentencing Guidelines. In Dowdell, the three defendants argued that the district court had not properly arraigned them. ${ }^{281}$ The appellate court called upon the official reporter of the court to certify that "his notes of the proceedings showed that the plaintiffs in error were arraigned, waived reading of the complaint and pleaded not guilty."282 The district court judge testified "that the reporter was the duly appointed, qualified

274. U.S. CoNST. amend. VI.

275. Id.

276. See, e.g., Castellanos, 882 F.2d at 474.

277. 221 U.S. 325 (1911).

278. Id. at 330 .

279. Id. at $330-31$.

280. Id. at $329-30$.

281. Id. at 328 .

282. Id. 
and acting reporter of the district."283 The reporter's certificate merely echoed the clerk's certificate. ${ }^{284}$

Therefore, the testimony by the three court officials did not affect the defendants' liberty interests. Instead the information was merely procedural. These individuals were not witnesses against the accused, because they did not threaten any liberty or property interest $t^{285}$ of the accused at trial. In sentencing hearings, however, those presenting information have a profound impact upon the liberty interest of the defendants.

Because rehabilitation is no longer the goal of sentencing, the length of time it will take to reform the convict is no longer an important issue. Instead, sentencing is now an extension of the determination of guilt or innocence. The government seeks to punish the offender, or deter future crime, by deciding the seriousness of the offense in question and allocating punishment accordingly. This process was intended to achieve added reliability and fairness in the system, but it changed sentencing to an analysis of the defendant's relative guilt. Thus, those presenting information at sentencing are witnesses as to guilt or innocence.

The Guidelines have merely separated the determination of guilt or innocence into two factfinding endeavors. The first, at trial, is a broad determination of overall blameworthiness. The second, at sentencing, is a fine-tuning designed to punish those similarly situated, with close to equal sentences.

Justice Scalia supported this view in his dissent in Mistretta $v$. United States. ${ }^{236} \mathrm{He}$ stated, "While the products of the Sentencing Commission's labors have been given the modest name 'Guidelines,' they have the force and effect of laws, prescribing the sentences criminal defendants are to receive."287 The Sentencing Commission has made sentencing a mini-trial in which the factual determinations of relative guilt or innocence have great effect on the defendant's liberty and property.

Justice Scalia also indicated that many of the Congressionally mandated statutory ranges are from zero to life. ${ }^{288}$ This fact fur-

283. Id.

284. Id.

285. Fines can be assessed under the Guidelines. See GuIDELINES MANUAL, supra note $2, \S 5 \mathrm{E} 1.2$.

286. 488 U.S. 361 (1989).

287. Id. at 413 (Scalia, J., dissenting) (citations omitted).

288. Id. 
ther evidences that the sentencing system of today is the two-step process described above. If Congress gives no more direction than providing a range of zero to life, then the sentencing judge's determination of facts is indeed of utmost importance.

b. Sentencing falls in the category "criminal prosecutions." The Sixth Amendment begins with the phrase "In all criminal prosecutions," and then explains the rights that will be protected. The majority opinion in United States v. Kikumura ${ }^{259}$ asserted that "criminal prosecution" does not include sentencing. ${ }^{290}$ According to Kikumura, once the trial court has found a defendant guilty, arguably the criminal prosecution has ended. ${ }^{291}$

Courts have extended other rights protected by the Sixth Amendment past trial, though. The right of assistance to counsel has been held applicable at sentencing. ${ }^{292}$ In addition, the sentencing judge must inform the defendant of the nature of the information considered. ${ }^{293}$ Each protection has been weighed in light of the type of hearing at issue to determine its necessity to the defendant. Therefore, because courts have extended some of the protections of the Sixth Amendment past trial, each individual protection and individual hearing must be analyzed. Further, as noted above, it is far from clear that the criminal prosecution or the determination of guilt or innocence is finished when the trial ends. $^{24}$

c. The Guidelines commentary does not exclude the Confrontation Clause from sentencing. The Commentary to section 6A1.3 of the Sentencing Guidelines states:

In determining the relevant facts, sentencing judges are not restricted to information that would be admissible at trial. Any information may be considered, so long as it has "sufficient indicia of reliability to support its probable accuracy." Reliable hearsay evidence may be considered. Out-of-court declarations by an unidentified informant may be considered "where there is good

289. 918 F.2d 1084 (3d Cir. 1990).

290. Id. at 1102 .

291. Id.

292. Mempa v. Rhay, 389 U.S. 128, 137 (1967).

293. See Wayne R. Lafave \& Jerold H. Israel, Criminal Procedure, § 26(e), at 1109-10 (2d ed. 1992).

294. See supra notes $287-89$ and accompanying text. 
cause for the nondisclosure of its identity and there is sufficient corroboration by other means." Unreliable allegations shall not be considered. ${ }^{295}$

Because the Commentary states that reliable hearsay can be considered, opponents of extending the Confrontation Clause to sentencing argue that sentencing courts can consider testimony without confrontation. United States v. Miller ${ }^{296}$ and United States $v$. Robinson $^{297}$ support this argument, both holding that reliable hearsay testimony can be admitted.

The test for reliable hearsay, however, should include analysis under the Confrontation Clause. The Guidelines commentary does not state that it excludes the Confrontation Clause from this test for reliability, because it does not have the power to do so. Disputed facts, which "have a measurable effect on the applicable punishment," ${ }^{298}$ should be tested under the Confrontation Clause to ensure their reliability. If application of the Confrontation Clause would exclude information, then that information must not have been reliable. United States $v$. Silverman ${ }^{299}$ supports this position, stating that "the reliability of the district courts' findings of fact must be tested under the principles established by the Confrontation Clause. ${ }^{3300}$

2. The Confrontation Clause Is a Trial Right. Some cases, although not dealing with sentencing, have referred to the Confrontation Clause as a trial right. Dutton $v$. Evans ${ }^{301}$ stated that the Confrontation Clause applies to "the truth-determining process in criminal trials. ${ }^{302}$ In Coy v. Iowa, ${ }^{303}$ the court applied the Confrontation Clause only to "those who appear and give evidence at trial." ${ }^{204}$ As well, Kentucky v. Stincer ${ }^{305}$ posited that the Con-

295. GUIDELINES MANUAL, supra note $2, \S 6 \mathrm{~A} 1.3 \mathrm{cmt}$. (citations omitted).

296. 910 F.2d 1321, 1328 (6th Cir. 1990), cert. denied, 111 S. Ct. 980 (1991).

297. 898 F.2d 1111, 1115 (6th Cir. 1990).

298. GUIDELINES MANUAL, supra note 2 , $\S 6$ A1.3 cmt.

299. 1991 WL 179608 (6th Cir. Sept. 17, 1991), vacated, 976 F.2d 1502 (6th Cir. 1992) (en banc).

300. Id. at *9.

301. 400 U.S. 74 (1970).

302. Id. at 89 .

303. 487 U.S. 1012 (1988).

304. Id. at 1016 (quoting California v. Green, 399 U.S. 149, 175 (1970) (Harlan, J., concurring)).

305. 482 U.S. 730 (1987). 
frontation Clause applies only when it is needed to protect the opportunity for effective cross-examination. ${ }^{306}$

The Guidelines have changed the sentencing system enough so that it now falls under what courts have meant by a trial right. Specifically, three changes distinguish the Guidelines from the indeterminate system that preceded it, and explain why the Confrontation Clause can now be applied. The first change is the present two-tier guilt determination. Second, the goal of the sentencing system is no longer rehabilitation. Lastly, the Guidelines set up an adversarial system.

a. The two-tier guilt determination. Under the Guidelines the sentencing judge is no longer allowed to exercise complete discretion. Now, judges must conduct specific factual determinations that have specified sentence departures connected ${ }^{\circ}$ with them. These factual determinations are mini-trials that significantly affect the defendant's liberty interests. Therefore, sentencing has become a process for judging the relative guilt of the defendant, and is sufficiently like a trial that the Confrontation Clause should be extended to cover it.

b. The goals of sentencing. A major difference between the Guidelines system and the old indeterminate system is that Congress decided that rehabilitation is no longer the goal of federal criminal sentencing. ${ }^{307}$ Retribution, education, deterrence, and incapacitation has become the operating goals of the Guidelines. ${ }^{308}$ Further, the Sentencing Commission created the Guidelines with Congress's stated objective of decreasing sentence disparities between similarly situated offenders. ${ }^{309}$

Unfettered discretion to the sentencing judge is no longer the rule. The Guidelines have reduced the number of facts a judge must consider, while increasing the importance of the decisions that are made. The importance of reliable factfinding has therefore been elevated so that disparity in sentencing can be reduced as much as possible. Under a system designed to promote rehabilitation, the sentencing judge needed access to a large amount of

306. Id. at 740 .

307. 28 U.S.C. $\S 994(k)$ (1988).

308. Id. § 991(b)(2); 18 U.S.C. § 3553(a)(2) (1988).

309. GUIDELINES MANUAL, supra note 2, at 2. 
information in order to determine the individual defendant's capacity to be rehabilitated. The determinate system needs less information. This decrease in needed information serves to make sentencing much more like trial. The Guidelines call for individual factual determinations that then give a prescribed sentence enhancement. This procedure mimics the way trials call for the determination of a set number of facts that determine whether the defendant is guilty or innocent.

c. The Guidelines system is adversarial. The indeterminate system was not adversarial, but the Guidelines system is. ${ }^{310}$ In the indeterminate system, the sentencing judge conducted an investigation privately, independent of the lawyers. ${ }^{311}$ The old system did not allocate burdens of proof between the parties, and did not require the judge to base the sentence on the existence of a particular fact or group of facts. ${ }^{312}$ Also, there were no rules requiring judges to disclose the information utilized in the determination. ${ }^{313}$

The Guidelines system has completely changed the indeterminate, non-adversarial system by introducing the sentencing hearing and emphasizing accurate and reliable factfinding. ${ }^{314}$ The Guidelines have made the finding of particularized facts (for example, existence of a weapon, knowledge that the money came from the sale of narcotics) dispositive upon the sentence that will be received. Sentences may double, triple, or even increase tenfold due to the existence of these facts. ${ }^{315}$ Also, defendants are allowed access to the information being used against them, and are allowed to present their own evidence pertaining to that information. The Guidelines themselves recognize the added importance of reliable factfinding. ${ }^{316}$ They note that adversarial hearings will sometimes be necessary to ensure reliability of information. ${ }^{317}$ The ad-

310. United States v. Silverman, 1991 WL 179608, at *7 (6th Cir. Sept. 17, 1991), vacated, 976 F.2d 1502 (6th Cir. 1992) (en banc).

311. Id.

312. Id.

313. Id.

314. Id.

315. Id.

316. See GUIDELINES MANUAL, supra note $2, \S 6$ A1.3 cmt. ("An evidentiary hearing may sometimes be the only reliable way to resolve disputed issues."):

317. See id. 
versarial nature of the Guidelines further characterizes the sentence hearing as a mini-trial, and thus brings it within the power of the Confrontation Clause.

\section{CONCLUSION}

Confrontation rights should apply at sentencing under the Due Process Clause of the Fourteenth Amendment and the Confrontation Clause of the Sixth Amendment. The analyses of these two Clauses are different, but both effectively extend confrontation rights to sentencing.

Much has changed since the courts analyzed whether the Due Process Clause mandated confrontation under the indeterminate sentencing system. The restructuring of the sentencing system has greatly increased the defendant's liberty interests at risk under the Guidelines. The limited appellate review of this process has enhanced the chance that those interests will be erroneously deprived. Also, because rehabilitation is no longer a goal, and the Guidelines system has limited information needed at sentencing, the extension of due process confrontation rights will not be impractical for the government. Therefore, under the Guidelines the Due Process Clause mandates confrontation during sentencing.

The Confrontation Clause protects against "anonymous accusers, and absentee witnesses." ${ }^{\text {"18 }}$ Individuals who present information at sentencing are witnesses against the accused. The Confrontation Clause must be extended to protect against anonymous accusers presenting false information. The sentencing hearing has changed under the Guidelines to an adversarial determination of guilt. Anonymous accusers should be restricted from depriving a defendant's liberty interests at these trial-like proceedings.

Again, recall John Doe's plight. Without confrontation rights during sentencing John had to serve a minimum of six months in prison. The only evidence of reliability of the information used against John was the DEA agent's assertion that the informant had proved reliable in the past. Allowing confrontation would have given John the opportunity to respond effectively to the information used against him. It also might have prevented him from spending six months in prison for crimes he did not commit.

318. United States v. Fatico, 441 F. Supp. 1285, 1297 (1977) (quoting California v. Green, 399 U.S. 149, 179 (1969) (Harlan, J., concurring)), rev'd, 579 F.2d 707 (2d Cir. 1978). 